\title{
The Role of Adjacency Pairs to Create Politeness Strategies in Students' Phatic Utterances
}

\author{
Ratna Padmi Trihartanti, ${ }^{*}$ Seldie Julyana Septiyan ${ }^{2}$ \\ English Department, Politeknik Negeri Bandung, Jl. Gegerkalong Hilir, Ciwaruga, Bandung \\ 40012, Indonesia
}

*) Corresponding Author

Email ratna.padmi@polban.ac.id

DOI: 10.18326/rgt.v14i2.243-262

Submission Track:

Received: 17-09-2021

Final Revision: 01-12-2021

Available Online: 05-12-2021

Copyright (C) 2021 Author(s)

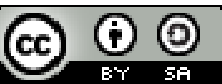

This work is licensed under a Creative Commons Attribution-ShareAlike 4.0 International License.

\begin{abstract}
Adjacency pair is one of the language features to make utterances more polite as it creates turn-taking, which means that none of participant dominates. Adjacency pairs also create functions of phatic communication as stated by Padilla Cruz. According to Levinson, there are nine patterns of adjacency pairs, and most could be found in utterances. The data were taken from 24 students' phatic utterances, and they were chosen because all participants are classmates. COVID-19 pandemic has forced them not to meet each other for almost 2 semesters, yet they show their closeness and solidarity. After all the data were analyzed using the qualitative method, it can be concluded that there are 7 adjacency pairs: QuestionAnswer, Offer-Accept, Taking leave-Taking leave, Summons-Answer, Request for information-Grant, Request-Apology, and Greeting-Greeting, and most of them have phatic functions of communication. Using adjacency pairs employs politeness strategies and negative and positive politeness strategies from Brown and Levinson. Negative politeness strategies found are: Be conventionally indirect, Question, hedge and Quality-hedges, while positive politeness strategies found are: Offer, promise, Include both $S$ and $\mathrm{H}$ in the activity, and Give gifts to H. One of adjacency- pairs, and phatic utterances' functions is to maintain politeness though the students are classmates with close social distance and equal power, they perform politeness strategies to keep their social relations. The appearance of politeness strategies shows that no matter how informal utterances are, closeness and politeness must stay together.
\end{abstract}

Keywords: adjacency-pairs; phatic utterances; politeness; strategies 


\section{INTRODUCTION}

Verbal communication is one medium that has been endlessly discussed since there are a lot of magic things to be dug deeper and deeper. One verbal communication discussed in the research is students' phatic utterances as a result of the adjacency pairs use. During the COVID-19 pandemic students have not met each other for more than a year, nor have they met somewhere outside campus because most of them live in different towns, yet they show their closeness and solidarity in their utterances before the online-class begins. Actually what they are talking about is not something serious, even they sometimes make jokes, and they are filled with longing to do excited things together, still they maintain politeness. Parts of their utterances sometimes do not share something important, and they have phatic functions. Padilla Cruz (2005) claimed that the phaticity of an utterance may be established by some factors and one of them is the occurrence in a particular conversational phase being part of an adjacency pair. From Padilla Cruz's statement, it can be drawn that parts of students' utterances in the present research can be called phatic utterances. Phatic communion then, later it becomes phatic communication is described as 'communication between people which is not intended to seek or convey information but has the social function of establishing or maintaining social contact' (Richard \& Schmidt, 2013, p. 432) here, students used adjacency pairs to show positive and negative politeness strategy. Daniels and Crystal (1992, p.415) define adjacency pair as a unit of conversation that contains an exchange of one turn each by two speakers'. For example, when speaker asks a question to hearer then, the latter will respond it. On the other occasion if speaker offers something, hearer may accept or refuse it in a good way. Though social distance among the students is symmetric, they try to avoid face threatening acts (FTAs), especially within the pandemic, they do not want to make any conflicts. By applying adjacency pairs, students try to maintain politeness. The aims of this study are to find out the types of adjacency pairs and phatic utterance functions mostly used in students' utterances and another aim is to analyze politeness strategies found in students' utterances.

Some research has discussed politeness in phatic utterances and adjacency pairs as we can see below: 
The first is from Padilla Cruz (2007). In his research entitled: 'Phatic Utterances and the Communication of Social Information: A Relevance Theoretic Approach', he offers an approach using relevance-theoretic that can make participant transmit and recover information about politeness in phatic utterances. By using this approach, speaker can communicate strongly and weakly at the same time. Moreover, hearer also can do as the speaker does and combines it with other contextual assumptions to gain contextual effects. In his paper, Cruz explains relevance theory in phatic utterances very clearly.

Next, Maros and Rosli (2017) wrote their research entitled: 'Politeness Strategies in Twitter Updates of Female English Language Studies Malaysian Undergraduates'. The research aims to contribute to the field of politeness and English language studies in Twitter updates to find out the most politeness strategies used. After having been analyzed using Brown \& Levinson' politeness theory, the 776 Tweet updates produced by the 9 female active users for 2 months, it shows that the Politeness strategies appear: bald on-record (33\%), positive politeness (37\%), negative politeness (7\%), and off-record (7\%). This research also assumes that positive politeness is used because the nature of Twitter encourages interpersonal communication and expression among the users.

Then, Bagheri et al. (2017) revealed a study: 'aha, ok, alright' as Phatic Talk: An Analysis on Opening in Multilingual and Multicultural Clinical Consultation'. The study analyzes six phases of clinical consultation, but it more focuses on the opening phase since it is considered to be the most primary care consultation between doctors and patients. It is believed that within consultation especially in opening phase, patients feel nervous and not comfortable because of his/her diseases; therefore, it will be good if doctors start with a small ritual talk before processing to the main point, that is patients' complaint. The phatic talk could be as opening, welcoming or greeting to break the 'excitement' belongs to patients so that they will feel more comfortable and create rapport between doctors and patients. In this study the use of 'aha, 'ok', and 'alright' as phatic talks are found many times.

The last, Kazemi and Azimifar (2019) conducted research on adjacency pairs by comparing the use of them in Computer Assisted Language Learning 
(CALL) to virtual classes. The result shows that there is no difference in the use of adjacency pairs in both classes compared to ordinary conversations. The most pattern of adjacency pairs appear mostly in both classes is Question Answer.

From the previous paper/research having been reviewed, none of them discusses adjacency pairs, politeness strategies and phatic utterances simultaneously. In this research, the writer aims to bridge the gaps by employing adjacency pairs with their functions of phatic communication, and politeness strategies.

Some theories are used in the present research among other is pragmatics. The term pragmatics was coined by Morris, a philosopher of language (1938) in order to label the science of relation of signs to their interpreter. Then, Ferrara (1985, p.138, cited in LoCastro, 2013, p. 5) defines pragmatics as 'the systematic study of the relation between the linguistic properties of utterances and their properties as social action'. Pragmatics has been divided into two main frameworks, and one of them is the early Anglo-Saxon framework of pragmatic study put forth mostly by philosophers of language who were interested in utterance rather than sentence meaning (Muller et al 2014, p.18 cited in Blitvich \& Sifianou 2019, p. 3). As a branch linguistics pragmatics is viewed from different approaches to maintain and focus on the use of language in social interaction and its effect that occurs to participant (Plaques \& Julian, 2017).

\section{Phatic Utterances}

Malinowski introduced the term phatic communion which later it becomes phatic communication or phatic utterances (1923) as this: phatic utterance is considered as a small talk because it does not produce serious talk. However, it has a significant function to build social relation. It can be said that the concept of phatic utterance is 'a type of speech in which ties of union are created by a mere exchange of words', or more pithily as 'speech communication used to establish social relationships' (Malinowski, 1923, p. 315). Furthermore, Malinowski reveals that phatic utterances have social function that might 'overcome the strange, unpleasant tension caused by silence' and/ or to create an atmosphere of sociability and personal communion between people (Malinowski, 1923 cited in Zegarac \& Clark, 2014, p.12) 
Realizing the significance of phatic utterances function in social relationship, Jakobson (1960) then, observes and divides it into six: emotive, connative, referential, phatic, metalingual and phoetic. Those derive from Malinowski's concept of phatic communion and Buhler's three language functions: expressive, appellative and representative. Jakobson claims the phatic function of language is function of language which emphasizes on the contact's presence between speaker and hearer in communication.

Some linguists who have given the contribution to the development of phatic functions are: Malinowski, Jakobson, Buhler, Leech, Cook, Holmes, Kridalaksana, Coupland, Richard et.al, Saunders, O' Sullivan, Mey, Renkema, Abercrombie and many more. Those linguists then, wrap their ideas into twelve functions of phatic communication. The theoretical framework is sketched out in the chart below:

\section{Theoretical Framework of Phatic Communication}

Malinowski's

phatic communion (1923)
Bühler's three language functions (1934)

expressive, appellative, representative

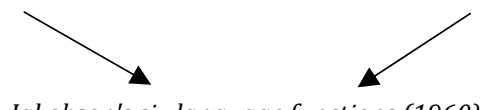

Jakobson's six language functions (1960):

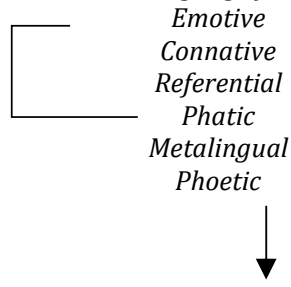

phatic communication:

Richards et al. (1985); Leech [1983], Cook [1989], Holmes [1992], Kridalaksana [1994, 2004],

O'Sullivan et al. [1994], Renkema [1994], Schiffrin [1994], Abercrombie [1998],

Verschueren [1999], Coupland [2000],], Mey [2001], Saville-Troike [2003]

12 functions of phatic communication: (1) breaking the silence, (2) starting a conversation, (3) making small talk, (4) making gossip, (5) keeping talking, (6) expressing solidarity,

(7) creating harmony, 8) creating comfort, (9) expressing empathy,

10) expressing friendship or camaraderie (11) expressing respect, (12) expressing politeness (Jumanto, 2006; 2014, p.9) 


\section{Adjacency Pairs}

Adjacency pairs are utterances produced by two successive speakers in such a way that the second utterance is identified as related to the first one as an expected follow up (Richards and Schmidt, cited in Shen, Xia, 2010). The next definition of adjacency pairs comes from (Heritage, cited in Wooffitt, 2011) who defines that the term adjacency pair is a sequence of two utterances which are adjacent, produced by different speakers, ordered as a first part and second part and typed. Thus, a first part requires a particular second, or range of second parts. The next definition of adjacency pairs is from Yule (1996, p. 77 cited in Mudra, 2018, p.4) He states that adjacency pairs are systematically produced in at two utterances by the speaker and the hearer respectively. Sacks et al. (1974) identified adjacency pairs as major turn types. Some patterns of adjacency pair are: Greeting-Greeting, Question-Answer, Complaint-Denial, Request-Apology, Request for information-Grant, Offer-Accept, SummonsAnswer, and Taking leave-Taking leave.

In this research, the present writer only writes those found in students' utterances. By using adjacency pairs, every participant will create turn-taking. Turn taking refers to the process by which people in conversation decide who to speak next (Ghilzai, 2015). The next definition of turn taking conveys that turn taking in conversation not only helps us apportion the floor, but also provides a symbolic function of helping the interactants to define their relationship (Wennerstorm \& Siegel, 2003). Turn taking also shows that participant maintains not only social interaction but also politeness.

\section{Politeness}

Politeness is a significant aspect of pragmatic competence. Mills states that politeness is 'the expression of the speakers' willingness to minimize face threatening carried by certain threatening acts toward another' (Mills, 2003, p.6 cited in Karimnia, 2018). William Folley, an anthropologist mentions politeness as 'a battery of social skills whose goal is to ensure feels affirmed in a social interaction' (Folley, 1997. p. 270 cited in Kadar \& Haugh, 2013. p.4) The two statements cover that politeness has a significant role to make participants of utterance feel comfortable as politeness is the soul to appreciate each other. Some linguists also stated their theories of politeness and among other is taken 
from (Lakoff 1975, p. 640) her notion of politeness is viewed as conversation that is conflict-free with interlocutors being able to satisfy each other's needs and interests by means of employing politeness strategies .... Meanwhile (Brown \& Levinson, 1987, p. 1) state that'... politeness, like formal diplomatic protocol (for which it must surely be the model), presupposes that potential for aggression as it seeks to disarm it, and makes possible communication between potentially aggressive parties'. From Lakoff and Brown and Levinson's theories of politeness, it can be concluded that politeness employs to mitigate confrontation occurs in utterances and to avoid FTAs.

Brown \& Levinson's theory of politeness (1987) consists of three basic notions: Face, Face Threatening Acts (FTAs), and politeness strategies. Face is the public self-image that every member of a society wants to claim for himself. The concept of face refers to a social representation of a person reflecting the respect, regard or confidence others have in them which person in question is conscious or aware of himself or herself (Goffman, 1972, p. 5 cited in Qi, 2017, p.3) Theory of face from Goffman, then was developed by Brown \& Levinson (1987) by stating that there are two kinds of faces which a person has as a public, namely positive face and negative face. Positive face is in which people want to be approved in a social community whereas negative face is in which people want to be appreciated. Another basic notion is Face Threatening Acts that defines as acts that infringe on the hearer's need to maintain his/herselfesteem. If there might be a tendency to threaten someone's positive or negative face, we can minimize it by using politeness strategies. Brown \& Levinson (1987, p. 103-132) divide it into two, namely: negative and positive politeness. Negative politeness strategies aim at hearer's negative face wants to describe expressions of restraint, formality, and distancing. On the other hand, positive politeness strategies aim to express solidarity and familiarity. To decide which strategies that are going to choose, there is a social variable with social power $(\mathrm{P})$, social distance (D) and ranking of imposition (R). Negative politeness will be used if the power of participants is not equal, and the social distance is not symmetric, so the rank of imposition is mostly low. Positive politeness strategies are chosen if participants have the same power, and symmetric social distance. Hence, the rank of imposition is not as low as negative politeness strategies, yet they are polite. 


\section{RESEARCH METHOD}

This research uses qualitative research as the result of data analysis is in descriptive forms. According to (Berg \& Lune, 2014, p.8 cited in Wang, 2018) 'Qualitative research properly seeks answers by examining various social settings and the groups or individuals who inhabit these settings'. Shakouri (2014) then adds that qualitative research is concerned with non-statistical methods of inquiry and analysis of social phenomena; moreover, Creswell makes those two theories of qualitative research clearer by completing that qualitative research is designed to explore grounded theory, ethnography, historical research and content analysis (Creswell, 2009 cited in Haradhan, 2014) From those theories, we can conclude that the most suitable method used in this research is qualitative because the data show the various social settings through students' utterances coming from different places and the result of analyzed data does not involve complicated calculation.

Participants of the research are the sixth semester students of the English department, Politeknik Negeri Bandung. They come from 2 classes and the number of them is 50, 27 students are from $3 \mathrm{~A}$, and 23 are from $3 \mathrm{~B}$. The sixth semester students were chosen as they have known each other for 4 semesters, and surely they studied in the same classes before COVID-19 pandemic occurs. They did a lot of activities in campus; hence, they experienced a lot of things together that make them close and have solidarity. The process of collecting the data started from asking the students to make utterances in pairs with free topics they chose. Free topics were given as they never meet each other face to face due to pandemic. First they conducted their utterances orally and recorded theirs. The next was they typed what they had uttered, and then, the head of the class sent his classmates' utterances via https:// drive.google.com. After all the data had been received, the present researcher downloaded and printed them out. There were 24 utterances collected. From the 24 utterances, it can be seen that the chosen topics are almost similar for examples: on line games, homework/assignments, pets, Korean dramas, sharing problems, and how they miss to attend to offline lessons. The next step was reading those utterances several times each to identify types of adjacency pairs, and to find out phatic functions. After finishing it, the process of analyzing was commenced to relate the types of adjacency pairs with the politeness strategies found. 


\section{RESULTS AND DISCUSSION}

From theoretical framework of phatic communication chart (Jumanto, 2006; 2014, p. 9), it presents that Malinowski's phatic communication and Buhler's three language functions have inspired Jakobson to develop both into: emotive, connative, referential, phatic, metalingual and phoetic. The development made by Jakobson is well-known as Jakobson's six language functions. One function, that is phatic, later expanded by some linguists into phatic communication. Phatic communication has 12 functions namely: breaking the silence, starting a conversation, making a small talk, making gossip, keeping talking, expressing solidarity, creating harmony, creating comfort, expressing empathy, expressing friendship, expressing respect, and expressing politeness.

After analyzing the 24 students' utterances, there are seven adjacency pair patterns created within the process of sharing the idea among them to maintain social relations. Those are: Greeting-Greeting, Taking leave-Taking leave, Question-Answer, Offer-Accept, Request-Apology, Summons-Answer, and Request for information Grant. From parts of each pattern, some of the phatic functions come up.

Greeting-Greeting pattern has function of phatic communication that is, starting a conversation by greeting another participant. It only found 3 times out of 24 utterances (2\%). Here, we can see the beginning of the utterance:

H: 'Неy...'

$\mathrm{K}$ : 'Hey, you'?

H: 'How are you man? 'You good'?

K: 'Yeah... I am good'

The next adjacency pair found in utterances is Taking leave-Taking leave. This adjacency pair usually appears when both participants want to end their communication. The function of phatic utterance here is to break the silence because the speaker does not know what to say anymore. It can be found 20 times (13.6\%). Below is an example of the utterances:

Z: 'The series are interesting and amazing.' '... Stay healthy'

A:' Ok... bye' 
Another adjacency pair found is Question-Answer, and it contains an expressing respect. This pattern found mostly among the other patterns. It is found 48 times or (32.6\%), and four of them shown below:

HY: 'Hey, I bought something, can you guess?'

RT: 'I have no ideas, I am sorry'

Y: 'T***** will you save it carefully?'

T: 'Sure...'

The function of phatic communication starts when RT says 'sorry' and in the second utterance it occurs when T agrees on doing something for Y. This type of adjacency pair is mostly found in students' utterances. The questionanswer pattern creates negative politeness strategies, and one of them is Be Conventionally Indirect which is found 48 times (42.9\%). According to Searle '... for a request to be felicitous (successful), the addressee must be thought potentially able to comply with the request, the requestor must want the thing requested, and so on (Searle, 1969 cited in Brown \& Levinson, 1987, p. 132). Though they are class mates, yet they maintain politeness by using indirect requests 'can' and 'will', and they are to minimize the imposition of utterance because in this strategy the speakers met opposing tensions.

The two other of Question-Answer patterns with different negative politeness strategies, and two functions of phatic utterances are found in these utterances: creating harmony and expressing empathy. DT creates harmony by thanking HT while KP encourages HT that the pandemic will be over next semester.

HT: 'Can you remember the file, tell me, will you?' 'Thank you'

DT: 'I will, thank you also for reminding me'

AP: 'Will we be graduated on line or offline?'

KP: 'I think, our graduation will be online'

AP:' Come on, don't say so. Don't you want to graduate offline?' 'I guess, we can be graduated offline'

KP:' I hope so. I absolutely believe that pandemic will be over next semester'.

We hope for the best' 
The utterances above still use Question-Answer adjacency pair, but they produce another negative politeness strategy that is, Question, hedge. We can see it when WI uses tag-question 'Tell me, will you?' which means 'I wonder whether you can tell me.'

We can also dig a different negative politeness strategy from the second utterance that is quality hedges. It is found 40 times or (35.7\%). The quality hedges found are: 'I think' and 'I guess' uttered by KP and AP. KP also uses a quality hedge: 'I absolutely believe...' According to Brown and Levinson (1987), quality hedges such as: 'I think', 'I guess' are used for expressing the situation when the speaker does not fully take responsibility for the truth of his utterance, or the speaker hesitates to the truth of his utterance. On the other hand, the use of 'I absolutely believe...' shows speaker's commitment to the truth of his utterance (Brown \& Levinson, 1987, p.164; Coates, 2014).

The next adjacency pair is Offer-Accept. It is used by speaker to offer something to hearer, and he accepts it. This pattern is found 28 times (19\%), and it contains expressing friendship of phatic utterance function as $\mathrm{Z}$ encourages $A$ to be keen on watching series to forget her ex.

Z:'What's wrong with you?'

A: 'Uh, I just broken with my boy- friend, and this is a terrible situation' How could I forget him?'

Z:' Try to watch movies or series then.' 'There are a lot of good movies and series or even Korean dramas'

A:' But I am not into Korean movies and stuff" 'I think I will not like it'

Z: 'You try it.' 'First, it is difficult for you to forget your ex, but I am sure, you will forget him soon'

From the utterance above, there is a positive politeness strategy, Offer, promise. It is mostly found in offer-accept pattern of adjacency pairs. According to Brown \& Levinson (1987) the function of this strategy is to redress the potential threat of some FTAs. S might choose to emphasize his cooperation with $\mathrm{H}$ in different way. He could claim that (during a specific sphere or relevance) whatever $\mathrm{H}$ wants, $\mathrm{S}$ wants for him and will assist to achieve. In the utterance above, $\mathrm{Z}$ as hearer offers $\mathrm{A}$, who acts as speaker to watch movies to forget her ex, and A agrees to do that. This strategy appears 24 times or (33\%). 
The next pattern of adjacency pair is Summons- Answer. It is found 18 times or (12.2\%) This pattern mostly happens because the internet connection is unstable, so speaker or hearer should summon his partner several times to make sure that they are still with him. This pattern has starting a conversation function of phatic communication.

$\mathrm{S}: \mathrm{F}^{* * * *}, \mathrm{~F}^{* * * *}$. Hello... $\mathrm{F}^{* * * *}$ Can you hear me?'

F: 'Yes, $\mathrm{S}^{* * * *}$, I can hear you' 'The connection sometimes is bad'

The next adjacency pair is Request-Apology pattern. It happens if speaker requests hearer to do something, but the latter refuses to do it by saying 'sorry'. This pattern creates expressing empathy phatic function, and it begins when $\mathrm{R}$ wishes $S$ gets better soon.

R:' I heard that $\mathrm{S}^{* * * * *}$ is sick. 'Can we make a video call with her?'

F:'No, sorry....' I think that we can't do it now.' 'Someone said that she infects from $c^{* * * * * * '}$

R: 'Give my regards' I hope she will be better soon'

Request-Apology patterns appear 12 times or (8.2\%). There is also Be Conventionally Indirect 'Can we make a video call with her' and another negative politeness strategy is Quality hedges' I think' that shows the speaker's hesitation.

The last pattern of adjacency pair found is Request for Information-Grant. It will perform if speaker asks Hearer to give information, and hearer provides it. It is found 18 times or (12.2\%). Expressing respect of phatic utterance's function occurs when M says sorry for not going to Z's house now:

$\mathrm{M}:$ ' $\mathrm{Z}^{* * *}$, do you still remember my laptop that I bought with you before pandemic?'

Z: 'Of course, I remember well.' After you bought it, you treated me meatball.'

'Let's do it again soon'

M: 'Oh, my God, we never know that pandemic will attach us.' There is a problem with my laptop, and I want to go there to serve it.'

$\mathrm{Z}$ : 'M******, do not make yourself in trouble. My neighbor is good at serving and repairing laptops' 
M: 'Will do', but sorry, perhaps two months later' 'I do not want to make your family worried because it is still pandemic.'

The utterance above shows that $\mathrm{M}$ requests for information to $\mathrm{Z}$, and he provides it. There are 2 positive politeness strategies, and the first is Include both $\mathrm{S}$ and $\mathrm{H}$ in the activity. This strategy shows an inclusive 'we' when $\mathrm{S}$ intends to involve 'You' and 'me'. Speaker can ask for the cooperative assumptions and redress FTAs. 'Let's in English is an inclusive 'we' (Brown \& Levinson, 1987). This strategy shows up 28 times or (38.9\%).

Another positive politeness strategy is Give gifts to $\mathrm{H}$. M as speaker knows that he may satisfy Z's positive-face want as hearer. In this situation $\mathrm{M}$ gives $\mathrm{Z}$ gifts by showing his understanding that he will not go to $\mathrm{Z}$ ' house now. This politeness strategy occurs 20 times or (27.8\%).

From the result above, we can see that some parts of the students' utterances with the adjacency pair patterns function as phatic communication, such as: expressing respect, expressing empathy, expressing friendship, starting a conversation, and breaking the silence. From those parts of phatic utterances, it can be seen that they do not share the idea, so they are in line with Malinowski's statement that phatic communion is not used to exchange the idea, but it aims to create bonds in a social society (1923). Jumanto (2014) analyzed phatic communication among English native speakers with the primary data were taken from interview. He concluded that all phatic utterances among them are in line with Malinowski's phatic communion theory, Buhler's expressive, and appellative functions of language, also Jakobson's phatic function of language theory, and Halliday's interpersonal function of language. Jumanto's research results 12 functions of phatic communication for creating ties of union. Kulkarni (2014) states that phatic functions are obviously established to initiate utterances, commence communication and interaction.

On the other hand, Rahardi (2017) disagrees with Malinowski's theory that phatic functions are' a mere exchange of words'. According to him, culturespecific phatic communion is different from Malinowski's theory. Having applied the pragmatics and sociolinguistics theories including the theories of contexts and phatic communication, Rahardi finds out that phatic functions can be employed to reveal speaker's meaning, be it informative and other functions. 
Yan (2010) conducted research on adjacency pairs found in phatic utterance. She focuses on politeness in the three patterns of adjacency pair: Greetings, Compliments and Directives, and she tried to find out how male and female make differences in applying those adjacency pairs. Yan compares how males and females express their politeness in their phatic utterances, yet the politeness strategies are not discussed as the present researchers do. Meanwhile Tsui (1985) only discusses the use of adjacency pairs among male and female students. She merely stresses on the least adjacency pair patterns found that is, Greeting-Greeting, and the mostly used is the Question-Answer. The finding on the use of adjacency pairs is almost similar to the present research.

Unlike the previous research, the present research involves adjacency pair patterns in students' utterances. Adjacency pairs are chosen because some parts of their utterances can create phatic functions as declared by Padilla Cruz (2005). Those adjacency pairs employed by the students have phatic functions and their aims are to express respect, solidarity, and empathy. Comparing to the research conducted previously, the present research does not only emphasize on either adjacency pair or phatic utterances. It strongly, focuses also on the appearance of politeness strategies both positive and negative. Those strategies show that participants with equal social power, social closeness, solidarity, and familiarity remain polite in building their social relations.

The results of this research are concluded on the 3 graphs below:

\section{Graph 1}

Adjacency Pairs Found in Students' Phatic Utterances

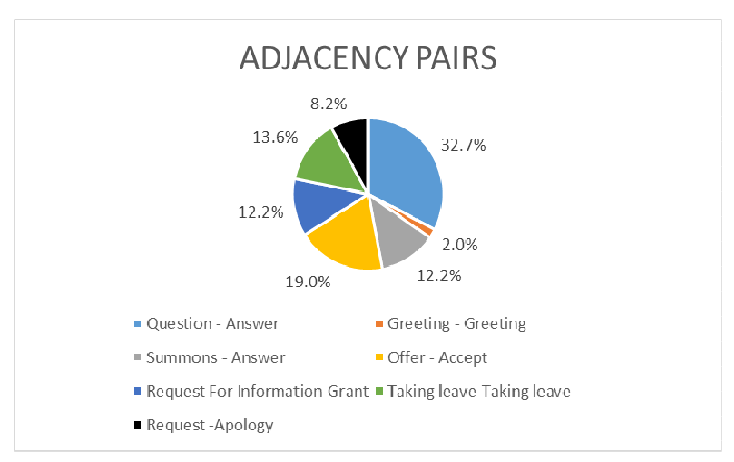




\section{Graph 2}

Negative Politeness Strategies Found in Students' Phatic Utterances

\section{NEGATIVE POLITENESS STRATEGIES}

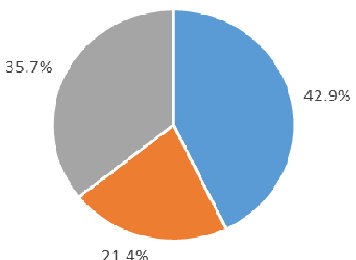

- Be Conventionally Indirect

- Question, Hedze

- Quality Hedges

\section{Graph 3}

Positive Politeness Strategies Found in Students' Phatic Utterances

POSITIVE POLITENESS STRATEGIES

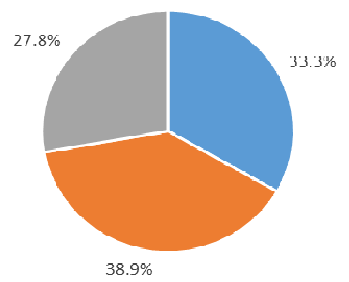

- Offer, Promise II Include Both Sand $\mathrm{H}$ in the activity = || Give gifts to $H$

\section{CONCLUSION}

From the result, it can be concluded that adjacency pairs found in the students' utterances have certain phatic functions, and those functions build phatic utterances. Some of the functions are not found such as making gossip and expressing politeness. Making gossip is not found because during the pandemic it is difficult for them to do that. While, expressing politeness phatic function is not conveyed since it is discussed from different point of view. During the pandemic, students' relationship is not as close as it was before the COVID-19 spreads. Hence, they try hard to make their friendship warm and polite through their phatic utterances to show their solidarity and closeness. The use of negative politeness strategies is to show respect, while positive 
politeness strategies is to express degree of solidarity, familiarity and sometimes informality. However, both politeness strategies found are to avoid face threatening acts (FTAs). The appearance of politeness strategies in students' phatic utterances using adjacency pair patterns have never been discussed in the previous research. So, it will share the new insights to all. For the next research, this kind of topic could be developed by adding respondents from different study programs, so it might increase the occurrence of politeness strategies and adjacency pairs.

\section{Acknowledgments}

The researchers would like to express their gratitude to the director of Politeknik Negeri Bandung, Dr. Rachmad Imbang T, M.T, and the head of SIPPM Politeknik Negeri Bandung, Prof. Ir. Sumeru, M.T, Ph. D, for their support and grant given in finishing this research.[rgt]

\section{REFERENCES}

Bagheri, H., Ibrahim, N. A., \& Habil, H. (2012). 'aha, ok, alright' as Phatic Talk: An Analysis on Opening in Multilingual and Multicultural Clinical Consultations. Procedia - Social and Behavioral Sciences, 66, 8-16. https://doi.org/10.1016/j.sbspro.2012.11.242

Beltrán-Planques, V., \& Querol-Julián, M. (2018). English language learners' spoken interaction: What a multimodal perspective reveals about pragmatic $\begin{array}{lll}\text { competence. System, } & \text { 80-90. }\end{array}$ https://doi.org/10.1016/j.system.2018.01.008

Blitvich, P. G. C., \& Sifianou, M. (2019). Im/politeness and discursive pragmatics. Journal of Pragmatics, 145, 91-101. https://doi.org/10.1016/j.pragma.2019.03.015

Blutner, R. (2016). Politeness: Some Universals in Language Usage. STUF - Language Typology and Universals, 42(1). https://doi.org/10.1515/stuf-1989-0124

Brown, P., \& Levinson, S. (1987). Universals in Language Usage: Politeness Phenomena. In E. Goody (Ed.), Questions and Politeness: Strategies in Social Interaction (pp. 56-310). Cambridge: Cambridge University Press. 
Bühler, K. (1918). Theory of Language: The Representational Function of Language. John Benjamins Publishing Company.

Charles W. Kreidler. (1998). Introducing English Semantic. London: Routledge.

Coates, J. (2014). Women, Men and Language. Women, Men and Language. https://doi.org/10.4324/9781315835778

Daniels, P. T., \& Crystal, D. (1992). The Cambridge Encyclopedia of Language. Language, 68(2), 422. https://doi.org/10.2307/416962

Ghilzai, S. A. (2015). Conversational Analysis of Turn taking Behavior and Gender Differences in Multimodal Conversation Shazia Akbar Ghilzai December 2015. Perspectives in Language, Linguistics and Media, 1(December), 1-13.

Gradinaru, C. (2018). Small talk in our digital everyday life: The contours of a phatic culture. Meta, 10(2), 459-472.

Haradhan, M. (2018). Qualitative Research Methodology in Social Sciences and Related Subjects. Journal of Economic Development, Environment and People, 7(1), 23-48.

Jakobson, R. (1960). Concluding statement: Linguistics and poetics. Style in language, 350-357.

Jumanto, Jumanto. (2006). Phatic Communication among English Native Speakers. University of Indonesia Dissertation.

Jumanto, Jumanto. (2014). Phatic Communication: How English Native Speakers Create Ties of Union. American Journal of Linguistics,3(1),9-16. https://doi.org/10.5923/j.linguistics.20140301.02 Determining.3(1),30-43.

Kádáar, D. Z., \& Haugh, M. (2013). Understanding politeness. In UnderstandingPoliteness. https://doi.org/10.1017/CB09781139382717

Karimnia, A. (2018). Patterns of Politeness in Teacher-Student Interaction: Investigating an Academic Context Patterns. October

Kazemi, A., \& Azimifar, F. (2019). A conversation analytic study of virtual vs. CALL language classes: With reference to adjacency pairs. International Journal of Language Studies, 13(3), 37-60.

Kulkarni, D. (2014). Exploring Jakobson's "phatic function" in instant messaging interactions. Discourse and Communication. https://doi.org/10.1177/1750481313507150 
Lakoff, R. (1975). Language and Societies Language and Societies. 637-657.

LoCastro, V. (2013). Pragmatics for Language Educators. Pragmatics for Language Educators. https://doi.org/10.4324/9780203850947

Malinowski, Bronislaw. (1923). The Problem of Meaning in Primitive Languages. In The Meaning of Meaning (pp. 296-336).

Maros, M., \& Rosli, L. (2017). Politeness strategies in twitter updates of female english language studies Malaysian undergraduates. 3L: Language, Linguistics, Literature, 23(1), 132-149. https://doi.org/10.17576/3L-2017-2301-10

Morris, C. H. (1938). Foundation of the theory of signs. In International Encyclopedia of Unified Science, 2(1). Chicago: University of Chicago Press

Mudra, H. (2018). Adjacency Pairs As Uttered in the Conversations of Sofia Coppola'S Lost in Translation Movie Script. Humanus, 17(1), 126. https://doi.org/10.24036/humanus.v17i1.8050

Padilla Cruz, M. (2005). On the phatic interpretation of utterances: A complementary relevance-theoretic proposal. Revista alicantina de estudios ingleses, 18 (Nov. 2005); pp. 227-246.

Padilla Cruz, M. (2007). Phatic Utterances and the Communication of Social Information: a Relevance-Theoretic Approach. Studies in Intercultural, Cognitive and Social Pragmatics, July, 114-131.

Purnomo, B. (2016). Politeness Strategies and Levels In Tourism-Service Language in Surakarta Residency. Register Journal, 3(2), 153-189. https://doi.org/10.18326/rgt.v3i2.447

Qi, X. (2017). Reconstructing the concept of face in cultural sociology: in Goffman's footsteps, following the Chinese case. Journal of Chinese Sociology, 4(1). https://doi.org/10.1186/s40711-017-0069-y

Rahardi, R. K. (2019). Extralinguistic context roles in determining meanings of javanese phatic expression 'mboten': A sociopragmatic perspective. International Journal of Humanity Studies. https://doi.org/10.24071/ijhs.2019.030103

Richards, J. C., \& Schmidt, R. W. (2013). Longman Dictionary of Language Teaching and Applied Linguistics. Longman Dictionary of Language Teaching and Applied Linguistics. https://doi.org/10.4324/9781315833835 
Sacks, H., Schegloff, E. A., \& jefferson, G. (1978). A Simplest Systematics for the Organization of Turn Taking for Conversation**This chapter is a variant version of "A Simplest Systematics for the Organization of Turn-Taking for Conversation," which was printed in Language, 50, 4 (1974), pp. 696-735. An e. Studies in the Organization of Conversational Interaction, 7-55. https://doi.org/10.1016/b978-0-12-623550-0.50008-2

Searle, J. R. (1969). Speech acts: an essay in the philosophy of language. Cambridge: Cambridge University Press.

Shakouri, N. (2014). Qualitative research: incredulity toward metanarrativeness. Journal of Education and Human Development, 3(2), 671-680. http://jehdnet.com/journals/jehd/Vol_3_No_2_June_2014/40.pdf

Shen, Q., \& Xia, T. (2010). Conversation Analysis as Discourse Approaches to Teaching EFL Speaking. Cross-Cultural Communication, 6(4), 90-103.

Tsui, A. B. M. (1989). Beyond the adjacency pair. Language in Society, 18(4), 545-564. https://doi.org/10.1017/S0047404500013907

Wang, J. (2018). Qualitative Research in English Language Teaching and Learning. Indonesian EFL Journal: Journal of ELT, Linguistics, and Literature, 4(2), 116132. http://ejournal.kopertais4.or.id/mataraman/index.php/efi

Wennerstrom, A., \& Siegel, A. F. (2003). Keeping the Floor in Multiparty Conversations: Intonation, Syntax, and Pause. In Discourse Processes (Vol. 36, Issue 2, pp. 77107). https://doi.org/10.1207/s15326950dp3602_1

Yan, X. (2010). Politeness Strategies in English Adjacency Pairs. Analysis.

Žegarac, V., \& Clark, B. (1999). Phatic interpretations and phatic communication. Journal of $\quad$ Linguistics, 35(2), 321-346. https://doi.org/10.1017/S0022226799007628 
This page has been intentionally left blank. 